\title{
Etnicidade / Ethnicity
}

https://doi.org/10.21814/uminho.ed.36.29 



\section{Etnicidade}

Etnicidade é o termo utilizado para definir um sentido coletivo de identidade por indivíduos que se veem ou são vistos por outros, como partilhando características que os distinguem de membros de outros grupos étnicos.

De diferentes formas, o conceito de etnicidade tem vindo a substituir o termo "raça" que é usado para categorizar indivíduos de diferentes grupos raciais baseada em características biológicas presumidas, que carece de validade científica e já não é utilizado para a classificação científica das populações. Atualmente, o termo "etnicidade" (ou, na sua variante, "grupo étnico") é frequentemente utilizado para se referir a um grupo existente num estado para ser distinguido de um outro dominante maioritário. Um grupo étnico é também distinguido de uma "nação" que tem uma identidade política mais explícita e que pode incluir mais do que um grupo étnico. Ainda que exista uma sobreposição significativa entre etnicidade, raça e nação e, ainda que na literatura sociológica sejam frequentemente distinguidos e matizados, na vida quotidiana, eles são utilizados intercambiavelmente e de modo muito mais livre. As tentativas teóricas para explicitar a etnicidade têm-se centrado, sobretudo, em duas grandes perspetivas, nomeadamente, primordialismo e circunstancialismo. 0 primordialismo considera a etnicidade como uma identidade básica e fundamental que permanece inalterada ao longo do tempo e é, por isso, primária para um sentido de pertença coletiva do indivíduo. O circunstancialismo, por outro lado, vê a etnicidade como identidade contextual que é construída e reconstruída ao longo do tempo, dependendo das circunstâncias nas quais o grupo se encontra.

A preocupação sociológica com a etnicidade tem criado um extenso corpo de literatura disponível que explora as múltiplas dimensões do fenómeno, desde as relações étnicas e conflitos ao multiculturalismo e integração, entre outros. Na Sociologia da Infância, a etnicidade tem recebido uma atenção mais limitada ainda que exista, claramente, um interesse emergente na exploração das identidades étnicas e o impacto da etnicidade nos mundos e vidas das crianças. Uma das linhas principais de trabalho na sociologia da infância tem lutado para desafiar as visões que entendem as crianças como passivas e à mercê de forças estruturais opressoras, procurando mostrar, inversamente, as crianças como seres ativos na construção das suas 
identidades étnicas e sentidos de pertença e capazes de moldar, em certa medida, os seus mundos sociais e políticos.

Muita da investigação em etnicidade e infância, particularmente no Norte Global, tem-se focado nas estruturas institucionais formais, como as escolas, onde a identidade étnica pode tornar-se, frequentemente, um fator saliente. Estes estudos exploram os desafios colocados pela diversidade étnica, cada vez mais presente em todas as sociedades multiculturais, e que tem vindo a intensificar-se como resultado dos movimentos migratórios, de refugiados e de requerentes de asilo. No entanto, nos últimos anos, existe um interesse crescente em explorar o modo como as crianças navegam as suas identidades étnicas para lá dos contextos institucionais, tais como a casa e a vizinhança, que lhes colocam diferentes desafios. Estes estudos têm salientado a fluidez e performatividade das identidades étnicas das crianças no fluxo da vida quotidiana, promovendo oportunidades para compreender a agência das crianças, através do terreno social (Pache \& Spyrou, 2012).

Um conjunto pequeno, mas em expansão, de estudos preocupados com o papel da etnicidade em relação ao nacionalismo em sociedades política e etnicamente divididas (por exemplo, Chipre, Israel/Palestina, etc.) tem elucidado o valor das abordagens da sociologia da infância que consideram quer o caráter constrangedor dos quadros ideológicos que informam as visões das crianças quer a sua capacidade para desafiar, resistir e reformulá-los. Estes estudos sublinham a significância da identidade étnica enquanto variável chave na compreensão do papel das crianças e da infância no conflito e na guerra, por um lado, e na paz, por outro.

Por último, e não menos importante, o conhecimento sobre infância e etnicidade tem reconhecido a importância de abordagens interseccionais na compreensão da construção de identidade. Os investigadores que exploram, numa perspetiva interseccional, as identidades étnicas das crianças consideram, entre outras, variáveis como género e classe social que apontam as complexidades dos processos identitários em curso. Esta abordagem ajuda a desessencializar o papel da etnicidade na infância mostrando que esta é apenas uma das variáveis que poderá ser mais ou menos significativa em diferentes contextos (ex, Morrow \& Connolly, 2006). 


\section{Ethnicity}

The term ethnicity is used to define a collective sense of identity by individuals who see themselves, or are seen by others, as having certain shared characteristics that distinguish them from members of other ethnic groups. Such shared characteristics may include a presumed common ancestry or biological traits, a shared history, culture, religion, or language.

The concept of ethnicity has, in many ways, replaced the term "race" which is used to categorize individuals in distinct racial groups based on presumed common biological characteristics, a concept which lacks scientific validity and is no longer used for the scientific classification of populations. Today, the term "ethnicity" (or its variant, "ethnic group") is often used to refer to a minority group existing within a state to be distinguished from a dominant majority group. An ethnic group is also distinguished from a "nation" that has a more explicit political identity and may comprise more than one ethnic group. Although there is significant overlap between ethnicity, race, and nation, and though in sociological literature they are frequently distinguished and nuanced, in daily life they are often used interchangeably and in a much looser fashion.

Theoretical attempts to explain ethnicity have centered mainly on two major perspectives, namely, primordialism and circumstantialism. Primordialism considers ethnicity to be a basic and fundamental identity that remains unchanged through time and hence is primary for an individual's sense of collective belonging. Circumstantialism, on the other hand, views ethnicity as a contextual identity that is constructed and reconstructed through time depending on the circumstances in which a group finds itself.

Sociological concern with ethnicity has given rise to an extensive body of literature, which explores multiple dimensions of the phenomenon, ranging from ethnic relations and conflict to multiculturalism and integration, among others. In the sociology of childhood, ethnicity has received more limited attention, although there is clearly an emerging interest in exploring children's ethnic identities and the impact of ethnicity on children's worlds and lives. One major approach from within the sociology of childhood has sought to challenge understandings of children as passive and at the mercy of overpowering structural forces, aiming to show instead that children are active in the construction of their own ethnic identities and sense of belonging. They are able to shape, to some extent, their social and political worlds. 
Much of the research on childhood and ethnicity, especially in the Global North, has focused on formal institutional structures such as schools, where ethnic identity may often become a salient factor. These studies explore the challenges posed by the ethnic diversity which is increasingly present in all multicultural societies, an issue which has been intensified further as a result of increased migration, refugee, and asylum seeker flows. In recent years, however, there is also an emerging interest in exploring how children navigate their ethnic identities beyond institutional contexts such as the home or the neighborhood which place different demands upon them. These studies highlight the fluidity and performativity of children's ethnic identities in the flow of everyday life offering opportunities for understanding children's agency across the social terrain (Pache \& Spyrou, 2012).

A small but expanding set of studies concerned with the role of ethnicity in relation to nationalism in politically and ethnically divided societies (e.g., Cyprus, Israel/Palestine, etc.) has elucidated the value of a sociology of childhood approach which considers both the constraining character of ideological frameworks which shape children's worldviews, as well as children's capacity to challenge, resist, and rework them. These studies highlight the significance of ethnic identity as a key variable in understanding the role of children and childhood in conflict and war on the one hand, and peace on the other.

Last but not least, the scholarship on childhood and ethnicity is recognizing the significance of intersectional approaches to understanding identity construction. Scholars who explore children's ethnic identities intersectionally consider, among others, variables such as gender and social class which pinpoint the complexities of the identity processes at work. This approach helps to de-essentialize the role of ethnicity in childhood by illustrating that it is just one social variable which may be more or less significant across different contexts (e.g., Morrow \& Connolly, 2006).

\section{Referências / References}

Morrow, V. \& Connolly P. (Eds.) (2006). Special Issue: Children and Ethnicity in Children's Everyday lives. Children and Society 20(2), 87-91.

Pache, V. \& Spyrou, S. (Eds.) (2012). Special Issue: Children's Interethnic Relations in Everyday Life - Beyond Institutional Contexts. Childhood, 19(3), 291-301. 